\title{
Influence of ENO juice orally taken in on the corrosion resistance of orthodontic wire made of SS 18/8 in the presence of artificial saliva
}

\author{
C.J.A. Priya, ${ }^{1}$ A.P.P. Regis ${ }^{1}$ and S. Rajendran ${ }^{2 *}$ \\ ${ }^{1} P G$ and Research Department of Chemistry, St Joseph's College, Tiruchirappalli, \\ 620 002, Tamilnadu, India \\ ${ }^{2}$ Research Director, Corrosion Research Centre, PG Department of Chemistry, St Antony's \\ College of Arts and Sciences for Women, Amala Annai Nagar, Tamaipadi, Dindigul, \\ 624 005, Tamilnadu, India \\ *E-mail: susairajendran@gmail.com
}

\begin{abstract}
Dentists make use of orthodontic wires such as SS 18/8, SS 316, Ni-Cr etc., to regulate the growth of teeth. In the saliva environment these wires undergo corrosion. Aside from this, they undergo corrosion by the food items, juices and tablets orally in taken. Corrosion resistance of SS 18/8 alloy in artificial saliva (AS), in the absence and presence of ENO fruit salt (lemon flavour) juice, has been investigated by polarization study and AC impedance spectra. It is inferred that corrosion resistance of SS 18/8 alloy in artificial saliva decreases in the presence of ENO. This is exposed by a decrease in linear polarization resistance $(L P R)$ value, decrease in charge transfer resistance $\left(R_{\mathrm{t}}\right)$ value, decrease in impedance value, increase in corrosion current and increase in double layer capacitance value $\left(C_{\mathrm{dl}}\right)$. In the presence of ENO, the $L P R$ value decreases from $3.488 \cdot 10^{6}$ to $1.629 \cdot 10^{6} \mathrm{Ohm} \cdot \mathrm{cm}^{2}$. The corrosion current value increases from $1.447 \cdot 10^{-8}$ to $2.637 \cdot 10^{-8} \mathrm{~A} / \mathrm{cm}^{2}$. The charge transfer resistance $\left(R_{\mathrm{t}}\right)$ value decreases from 37796 to $3068 \mathrm{Ohm} \cdot \mathrm{cm}^{2}$. The double layer capacitance value increases from $1.349 \cdot 10^{-10}$ to $1.662 \cdot 10^{-9} \mathrm{~F} / \mathrm{cm}^{2}$. The impedance value decreases from 4.857 to $3.954 \log (\mathrm{Z} / \mathrm{Ohm})$. It implies that people clipped with orthodontic wire made of SS 18/8 alloy should avoid taking ENO juice orally.
\end{abstract}

Keywords: orthodontic wires, SS 18/8, corrosion resistance, ENO juice, artificial saliva.

Received: July 9, 2021. Published: August 8, 2021

doi: $\underline{10.17675 / 2305-6894-2021-10-3-13}$

\section{Introduction}

Beautiful teeth are attractive. For some people the arrangement of teeth is not in a regular manner by God's greatness. To regulate the growth of teeth dentists make use of orthodontic wire made of various types of alloys such as SS 18/8, Ni-Cr, SS 316, thermoactive super elastic alloy, Gold $22 \mathrm{~K}$, Gold $20 \mathrm{~K}$ etc. After having clipped with orthodontic wires people take many food items, tablets, juice etc., orally. Apart from saliva, these food items may corrode the orthodontic wires. Therefore, a study on this aspect is necessary to know how 
far these wires are affected and corroded. More than a few research papers have been published in this regard.

The effect of glow discharge nitriding on the corrosion resistance of stainless steel orthodontic arches in artificial saliva solution has been investigated by Kamiński et al. [1]. They carried out a comparative study on orthodontic arch wires of AISI304 steel before and after low temperature plasma nitriding. Polarisation study and AC impedance spectra have been employed for this purpose. Microhardness was measured before and after treatment.

The power of snake fruit extract (Salacca zalacca) in inhibiting the release of chromium $(\mathrm{Cr})$ and nickel (Ni) ion from stainless steel orthodontic wire to saliva has been investigated by Erwansyah and Susilowati [2]. $\mathrm{Cr}$ and $\mathrm{Ni}$ ion release was measured using Atomic Absorption Spectrophotometry. The investigation was made on control group and treatment groups. Pre-tests and post-tests were conducted. It is obvious from this study that Snake fruit seeds extract effectively inhibits the Ni ions release from stainless steel orthodontic wire at a concentration of $300 \mathrm{ppm}$.

Musa Trolic et al. have examined the influence of probiotic supplements, recommended for use in orthodontic patients, on the corrosion stability of stainless steel and three types of NiTi orthodontic wires [3]. The corrosion resistance was calculated by polarization study and AC impedance spectra. It was noted that probiotic bacteria L. reuteri and probiotic supplement influence on a general corrosion rate as well as on likelihood of pitting corrosion occurrence. It was also noticed that their effect is dependent on the kind of alloy and coating.

Stainless steel 316L is extensively used in biomedical applications with respect to their excellent corrosion resistance, nonmagnetic properties, high ductility and acceptable biocompatibility. There have been made electrochemical studies in vitro in order to determine the corrosion reactions, which are necessary for foreseeing the behavior of the materials used in orthodontic applications. The degradation of metals and alloys in the human body is a combination of effects due to corrosion and mechanical activities. In dentistry, stainless steel 316L is used in a diversity of applications: sterilized instruments, endodontic files in root canal therapy, metal posts in root canal treated teeth, temporary crowns, arch wires and brackets in orthodontics, a necessary condition for these applications must to resist to pitting corrosion [4].

Agnes Brigitta et al. have investigated the effects of some tablets on orthodontic wire made of SS 316L alloy in Artificial Saliva [5]. Influence of some tablets on corrosion resistance of orthodontic wires made of SS 316L alloy in artificial saliva has been studied by Anandan et al. by making use of electrochemical studies such as polarization study and AC impedance spectra [6]. Renita D'souza et al. have considered corrosion resistance of SS 316L alloy in artificial saliva in the presence of Sparkle fresh toothpaste, by electrochemical studies [7]. Agnes Brigitta et al. have investigated corrosion resistance of SS18/8, Gold18 carat, Gold 22 carat and SS 316L alloy in artificial saliva in the absence and presence of Vitavion Fort tablet $500 \mathrm{mg}$ [8]. Influence of $D$-glucose on corrosion resistance of SS 316L in the presence of artificial saliva has been studied by Saranya and Rajendran by making use of electrochemical studies [9]. Zhang et al. have investigated the effect of the heat treatment 
on corrosion and mechanical properties of $\mathrm{CoCrMo}$ alloys manufactured by selective laser melting [10]. Corrosion behavior of $\mathrm{Co}-\mathrm{Cr}$ dental alloys processed by alternative CAD/CAM technologies in artificial saliva solutions has been studied by Savencu et al. [11].

The present work is undertaken to study the corrosion resistance of orthodontic wire made of SS 18/8 alloy in artificial saliva in the presence of ENO (juice), by electrochemical studies such as polarisation study and AC impedance spectra.

\section{Materials and Methods}

\section{Preparation of the metal specimens}

A thin wire of SS $18 / 8$ alloy is used as test material for this work. The chemical composition of the alloy is as follows: $18 \% \mathrm{Cr}, 8 \% \mathrm{Ni}$ and balance is Fe. The orthodontic wire was encapsulated in a Teflon rod. It was polished to mirror finish and used for electrochemical studies.

\section{Preparation of artificial saliva}

The preparation of artificial saliva was done using the composition of Fusayama Meyer artificial saliva (AS). Artificial saliva was prepared in laboratory and the composition of artificial saliva was as follows: $\mathrm{KCl}-0.4 \mathrm{~g} / \mathrm{L}, \mathrm{NaCl}-0.4 \mathrm{~g} / \mathrm{L}, \mathrm{CaCl}_{2} \cdot 2 \mathrm{H}_{2} \mathrm{O}-0.906 \mathrm{~g} / \mathrm{L}$, $\mathrm{NaH}_{2} \mathrm{PO}_{4} \cdot 2 \mathrm{H}_{2} \mathrm{O}-0.690 \mathrm{~g} / \mathrm{L}, \mathrm{Na}_{2} \mathrm{~S} \cdot 9 \mathrm{H}_{2} \mathrm{O}-0.005 \mathrm{~g} / \mathrm{L}$, urea $-1 \mathrm{~g} / \mathrm{L}$.

ENO juice

ENO fruit salt (lemon flavor) was used in the present study. This gives effective relief from acidity in a refreshing lemon flavor [12]. 500 ppm of ENO fruit salt (lemon flavor) was used in this investigation.

\section{Potentiodynamic polarization study}

A CHI 660A workstation model was used in the electrochemical studies. Polarization study was carried out using a three-electrode cell assembly (Scheme A). SS 18/8 was used as the working electrode, platinum as the counter electrode, and saturated calomel electrode (SCE) as the reference electrode. After having done IR compensation, the polarization study was carried out at a sweep rate of $0.01 \mathrm{~V} / \mathrm{s}$. The corrosion parameters such as linear polarization resistance $(L P R)$, corrosion potential $E_{\text {corr }}$, corrosion current $I_{\text {corr }}$ and Tafel slopes $\left(b_{\mathrm{a}}\right.$ and $\left.b_{\mathrm{c}}\right)$ were measured.

\section{Alternating current impedance spectra}

AC impedance spectra were recorded in the same instrument used for polarization study, using the same type of three electrode cell assembly. The real part $\left(Z^{\prime}\right)$ and imaginary part $\left(-Z^{\prime \prime}\right)$ of the cell impedance were measured in ohms for various frequencies. The charge transfer resistance $\left(R_{\mathrm{t}}\right)$ and double layer capacitance $\left(C_{\mathrm{dl}}\right)$ values were calculated. 


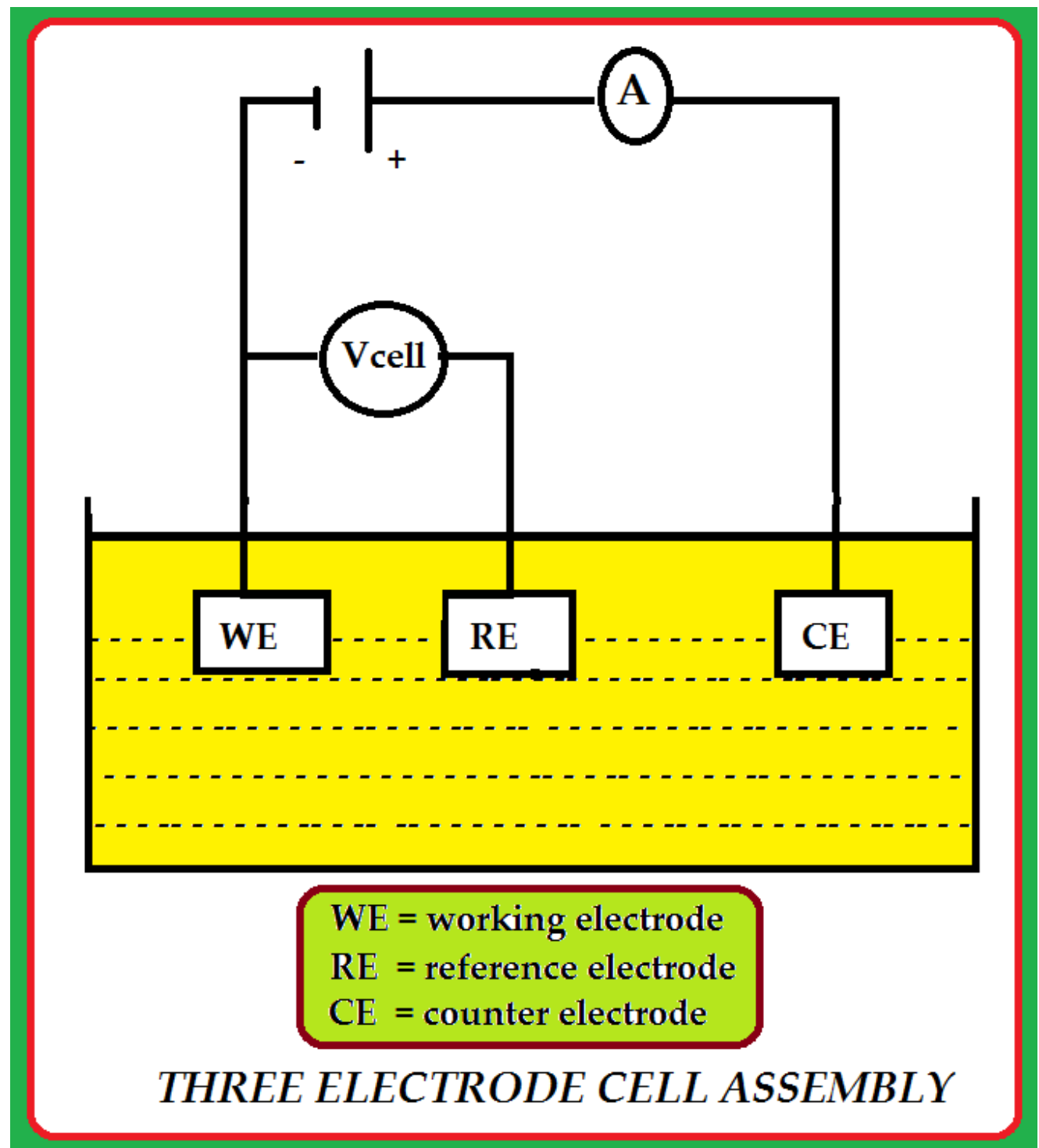

Scheme A. Three electrode cell assembly.

\section{Results and Discussion}

Influence of ENO on corrosion resistance of SS 18/8 alloy in artificial saliva

The influence of ENO on corrosion resistance of SS 18/8 alloy in artificial saliva (AS), has been investigated by polarization study and AC impendence spectra [13-22].

When corrosion resistance increases, linear polarization resistance increases, charge transfer resistance increases and impedance value increases. On the other hand, corrosion current decreases and double layer capacitance decreases [13-22]. However, when corrosion resistance decreases, linear polarization $(L P R)$ decreases, charge transfer resistance $\left(R_{\mathrm{t}}\right)$ decreases and impedance value decreases. On the other hand, corrosion current $\left(I_{\text {corr }}\right)$ increases and double layer capacitance $\left(C_{\mathrm{dl}}\right)$ increases (Scheme B). 


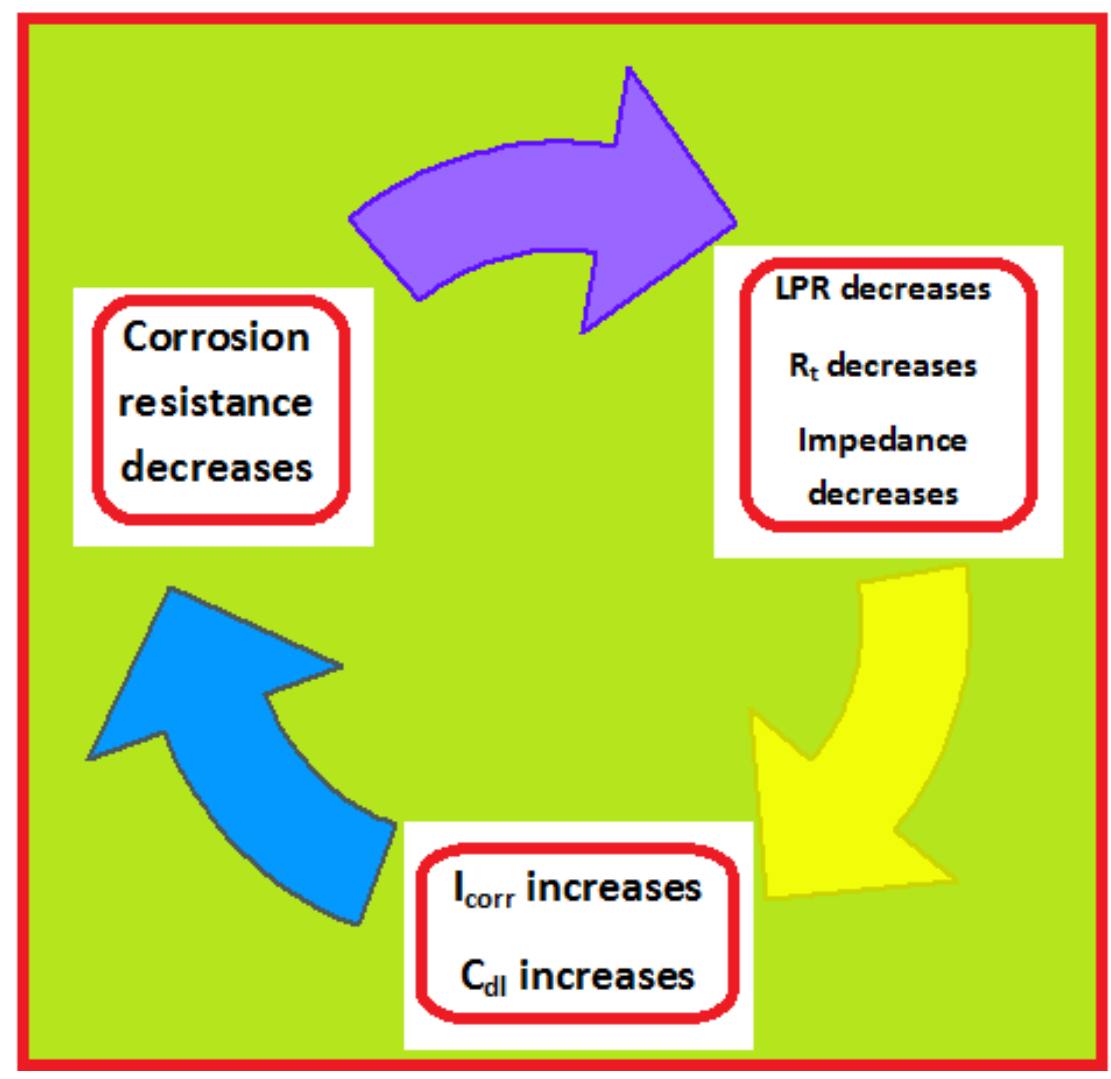

Scheme B. Correlation among corrosion parameters when corrosion resistance decreases.

\section{Polarization study}

In the present investigation polarization studies were carried out in a $\mathrm{CHI}$ Electrochemical work station/analyzer, model 660A. It was provided with automatic IR compensation facility. A three electrode cell assembly was used (Scheme A).

The working electrode was SS 18/8 alloy. A Saturated calomel electrode (SCE) was the reference electrode. Platinum foil was the counter electrode. A time interval of 5 to 10 minutes was given for the system to attain a steady state open circuit potential. From polarization study, corrosion parameters such as corrosion potential $\left(E_{\text {corr }}\right)$, corrosion current $\left(I_{\text {corr }}\right)$, Tafel slopes anodic $=b_{\mathrm{a}}$ and cathodic $=b_{\mathrm{c}}$ and $L P R$ (linear polarisation resistance) value were calculated. The scan rate $(\mathrm{V} / \mathrm{s})$ was 0.01 . Hold time at $\left(E_{\mathrm{fcs}}\right)$ was zero and quiet time $(\mathrm{s})$ was two.

The polarization curves of SS18/8 alloy in artificial saliva (AS) in the absence and presence of 500 ppm of ENO are shown in Figure 1. The corrosion parameters are given in Table 1.

It is observed from Table 1 that in the presence of ENO, the corrosion resistance of SS 18/8 in AS decreases. This is revealed by the fact that, in the presence of ENO, LPR value of SS 18/8 decreases (Figure 2) and corrosion current increases. 
Table 1. Corrosion parameters of SS $18 / 8$ immersed in Artificial Saliva (AS) in the presence of ENO (500 ppm) obtained from polarization study.

\begin{tabular}{cccccc}
\hline System & $\begin{array}{c}\boldsymbol{E}_{\text {corr }} \\
\mathbf{m V} \mathbf{v s ~ S C E}\end{array}$ & $\begin{array}{c}\boldsymbol{b}_{\mathbf{c}} \\
\mathbf{m V / d e c a d e}\end{array}$ & $\begin{array}{c}\boldsymbol{b}_{\mathbf{a}} \\
\mathbf{m V / d e c a d e}\end{array}$ & $\begin{array}{c}\boldsymbol{L P R} \\
\mathbf{O h m} \cdot \mathbf{c m}^{2}\end{array}$ & $\begin{array}{c}\boldsymbol{I}_{\text {corr }} \\
\mathbf{A} / \mathbf{c m}^{2}\end{array}$ \\
\hline AS & -276 & 169 & 388 & $3.488 \cdot 10^{6}$ & $1.447 \cdot 10^{-8}$ \\
AS+ENO & -351 & 182 & 216 & $1.629 \cdot 10^{6}$ & $2.637 \cdot 10^{-8}$ \\
\hline
\end{tabular}

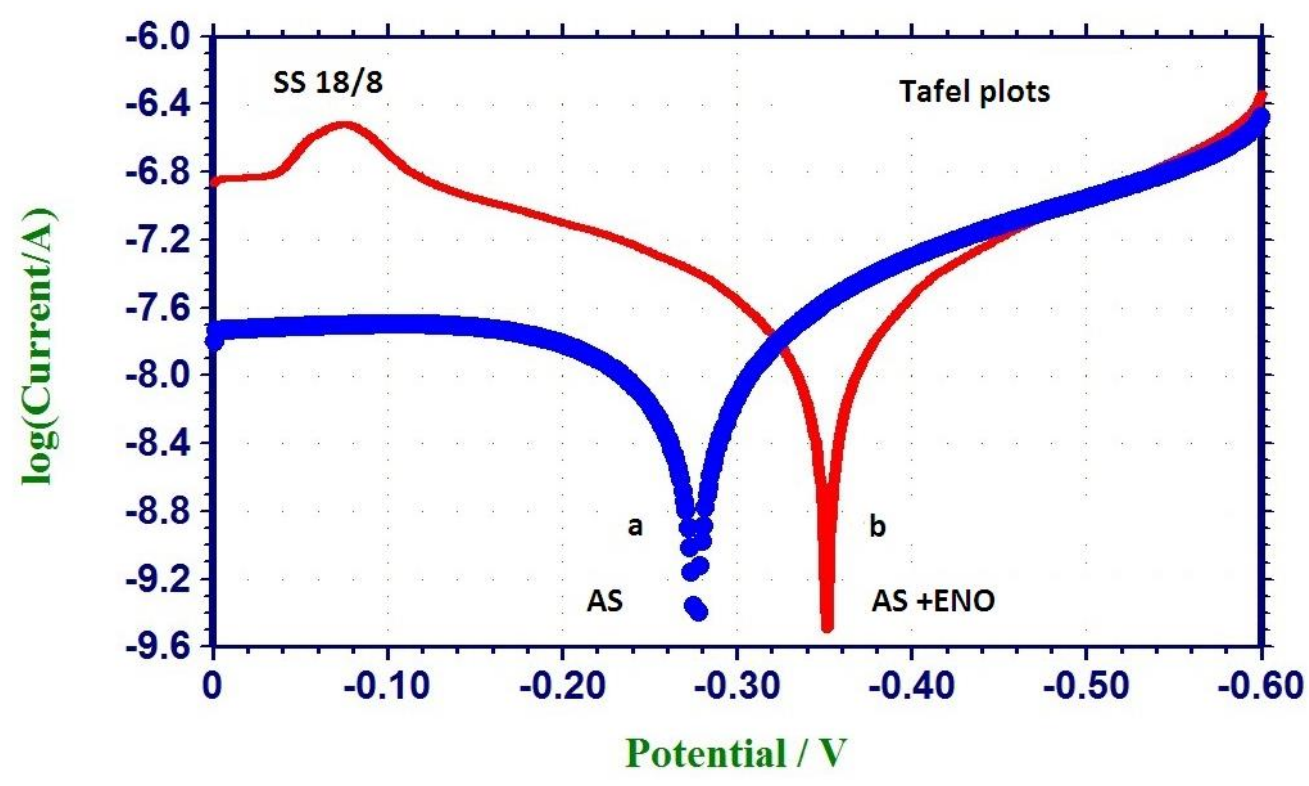

Figure 1. Polarisation curves of SS $18 / 8$ alloy immersed in various test solutions.

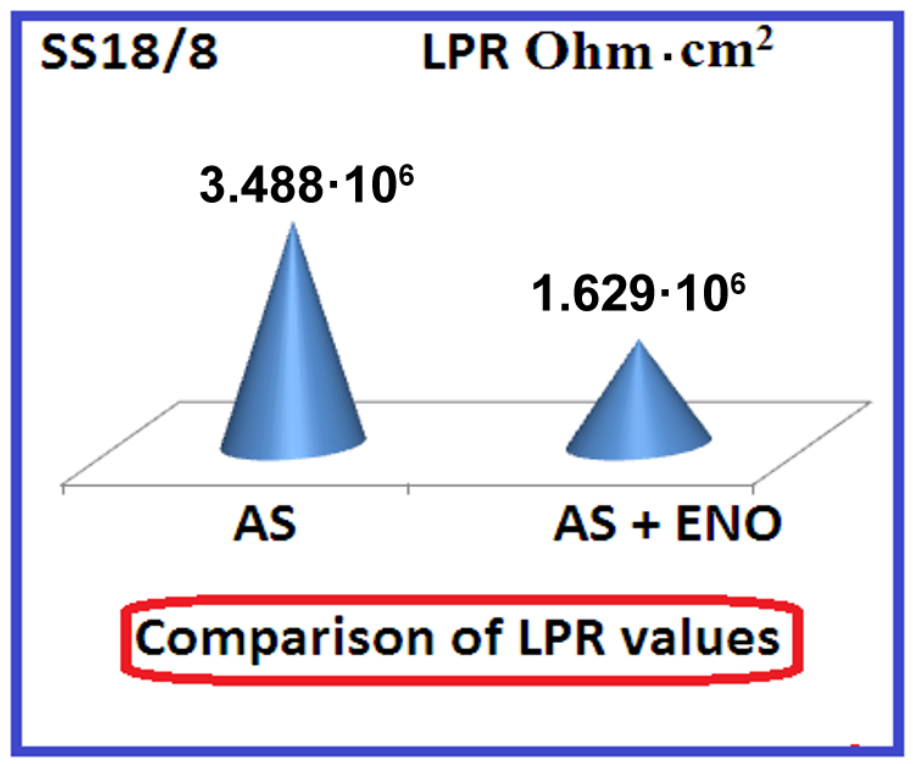

Figure 2. Comparison of LPR values. 
It is also observed that in the presence of ENO the corrosion potential shifts from -276 to $-351 \mathrm{mV} v s$. SCE. It is inferred that in the presence of ENO the cathodic reaction is controlled predominantly.

\section{Implication}

Corrosion resistance of SS 18/8 alloy in artificial saliva decreases in the presence of ENO. Hence people clipped with orthodontic wire made of SS 18/8 alloy should avoid taking ENO orally.

\section{AC Impedance spectra}

In the present investigation the same instrument set-up used for polarization study was used to record AC impedance spectra also. A time interval of 5 to 10 min was given for the system to attain a steady state open circuit potential. The real part $\left(Z^{\prime}\right)$ and imaginary part $\left(-Z^{\prime \prime}\right)$ of the cell impedance were measured in Ohms at various frequencies. AC impedance spectra were recorded with initial $E(\mathrm{~V})=0$, high frequency $\left(\mathrm{Hz}=1 \cdot 10^{5}\right)$, low frequency $(\mathrm{Hz}=1)$, amplitude $(\mathrm{V})=0.005$ and quiet time $(\mathrm{s})=2$. From Nyquist plot the values of charge transfer resistance $\left(R_{\mathrm{t}}\right)$ and the double layer capacitance $\left(C_{\mathrm{dl}}\right)$ were calculated.

$$
R_{\mathrm{t}}=\left(R_{\mathrm{s}}+R_{\mathrm{t}}\right)-R_{\mathrm{s}}
$$

Where $R_{\mathrm{s}}=$ solution resistance.

$C_{\mathrm{dl}}$ values were calculated using the relationship:

$$
C_{\mathrm{dl}}=\frac{1}{2} \cdot 3.14 \cdot R_{\mathrm{t}} \cdot f_{\text {max }}
$$

Where $f_{\max }=$ frequency at maximum imaginary impedance.

The AC impedance spectra of SS 18/8 alloy in AS in the absence and presence of $500 \mathrm{ppm}$ of ENO are shown in Figures 3, 4, 6 and 7. The Nyquist plots are shown in Figures 3, 4. The Bode plots are shown in Figures 6, 7.

The corrosion parameters such as change transfer resistance $\left(R_{\mathrm{t}}\right)$, impedance value and double layer capacitance $\left(C_{\mathrm{dl}}\right)$ values are given in Table 2.

Table 2. Corrosion parameters of SS 18/8 immersed in Artificial Saliva (AS) in the presence of ENO (500 ppm) obtained from AC impedance spectra.

\begin{tabular}{cccc}
\hline System & $\begin{array}{c}\boldsymbol{R}_{\mathbf{t}} \\
\mathbf{O h m} \cdot \mathbf{c m}^{2}\end{array}$ & $\begin{array}{c}\text { Impedance } \\
\mathbf{l o g}(\mathbf{Z} / \mathbf{O h m})\end{array}$ & $\begin{array}{c}\boldsymbol{C}_{\mathbf{d l}} \\
\mathbf{F} / \mathbf{c m}^{2}\end{array}$ \\
\hline AS & 37796 & 4.857 & $1.349 \cdot 10^{-10}$ \\
AS+ENO & 3068 & 3.954 & $1.662 \cdot 10^{-9}$ \\
\hline
\end{tabular}




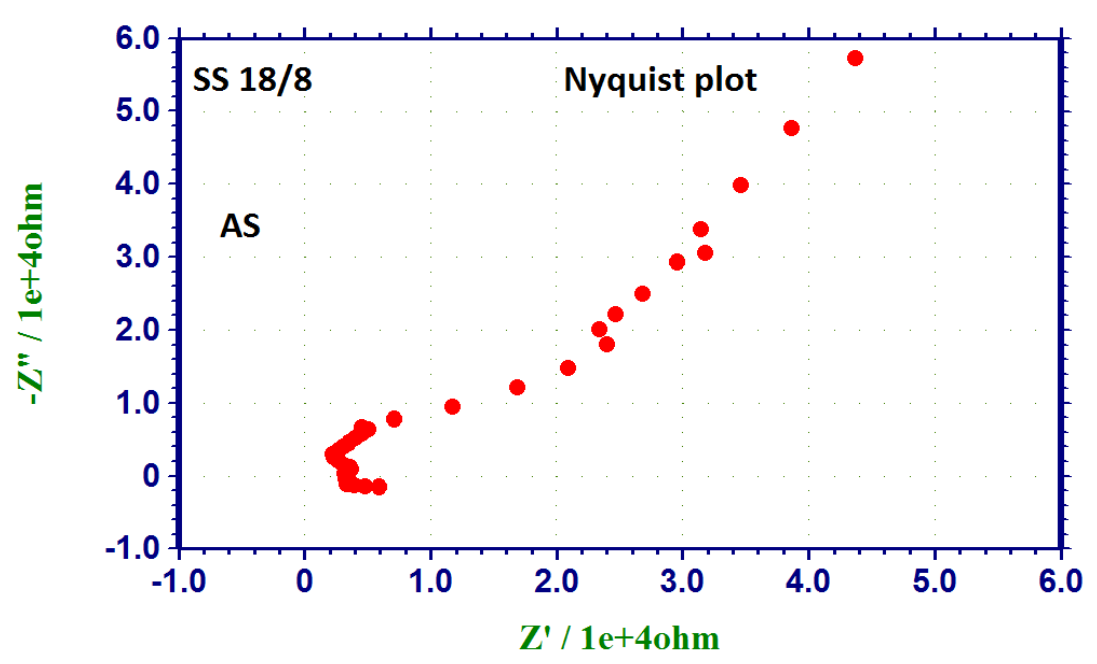

Figure 3. AC impedance spectrum of SS 18/8 immersed in Artificial Saliva (Nyquist plot).

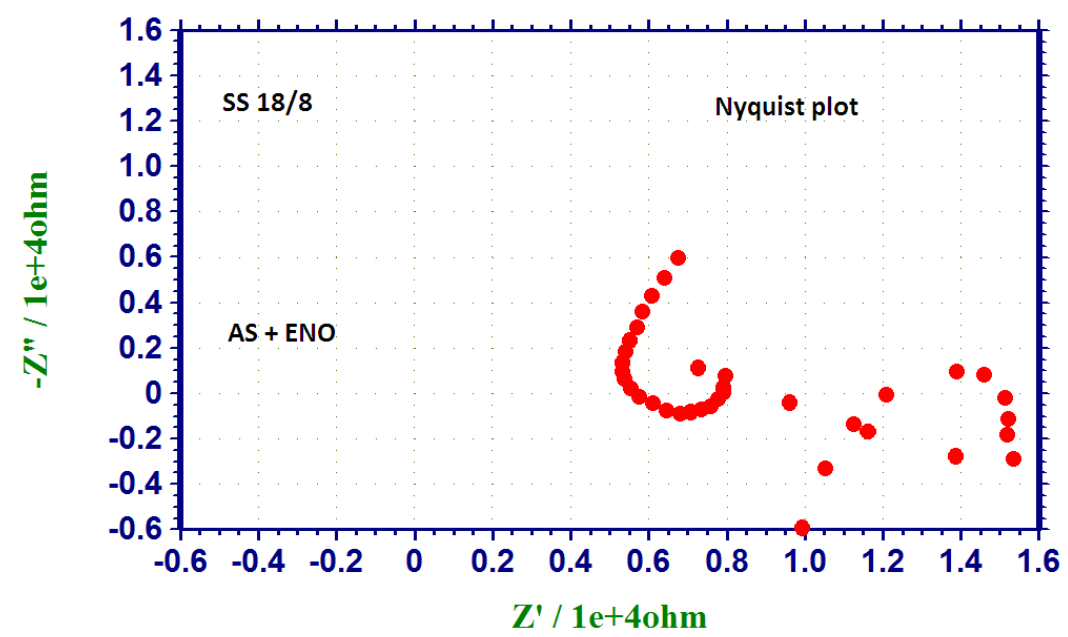

Figure 4. AC impedance spectrum of SS 18/8 immersed in Artificial Saliva+ENO (Nyquist plot).

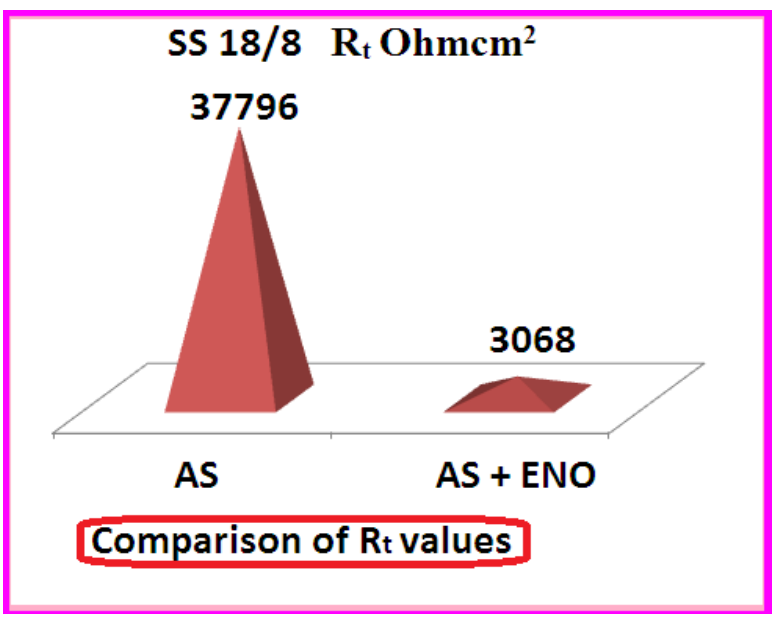

Figure 5. Comparison of $R_{\mathrm{t}}$ values. 

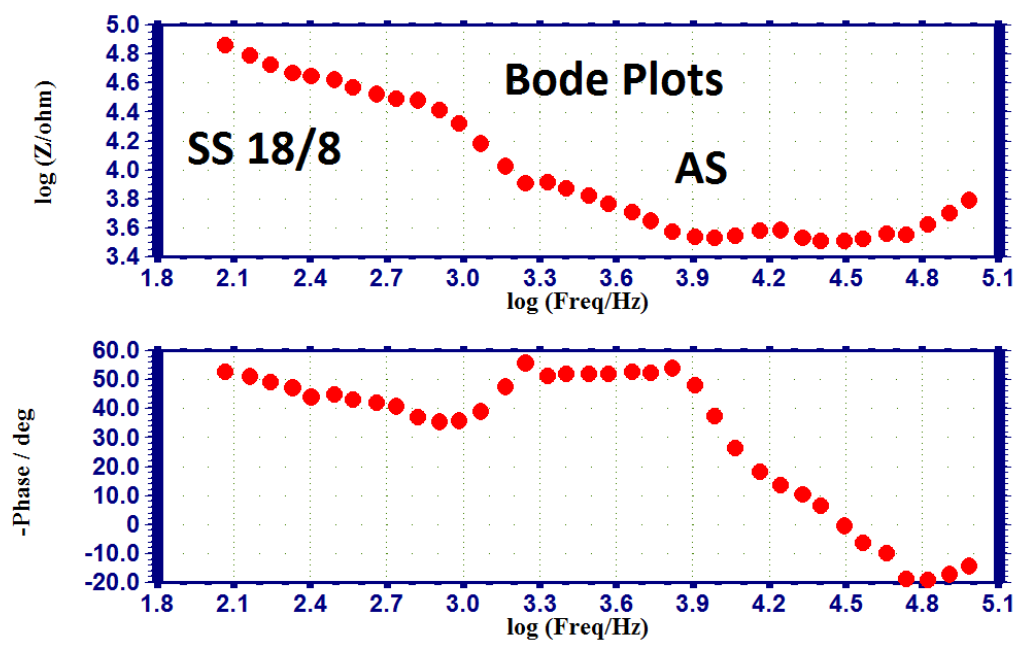

Figure 6. AC impedance spectrum of SS 18/8 immersed in Artificial Saliva (Bode plots).
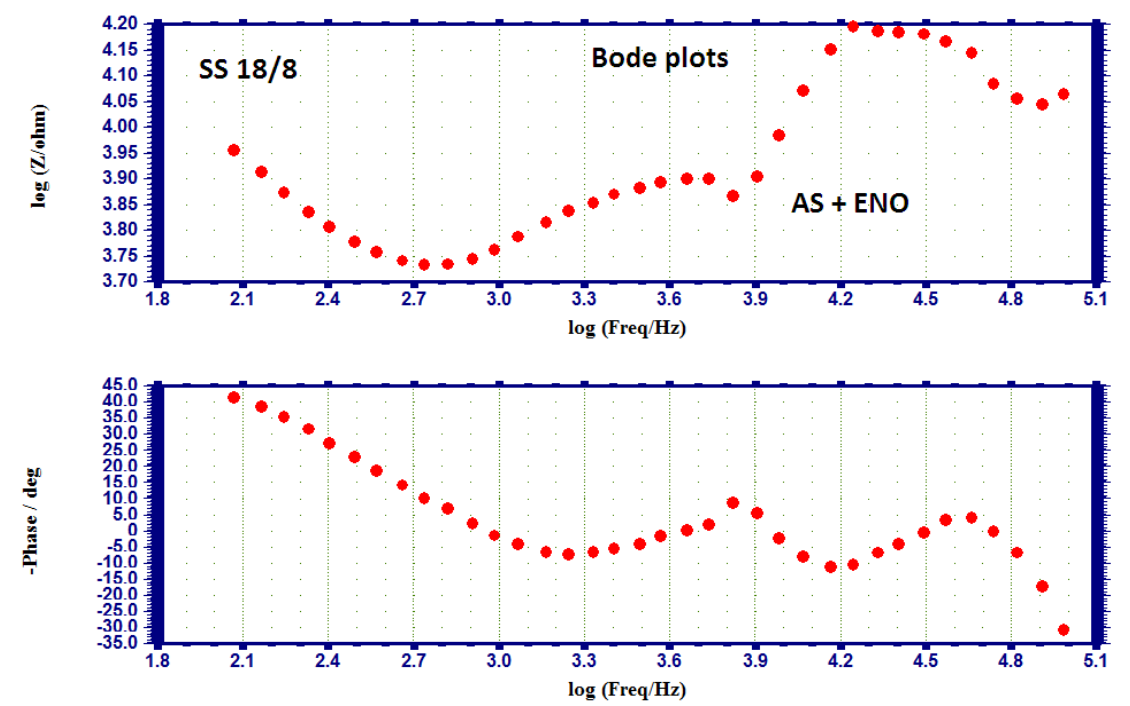

Figure 7. AC impedance spectrum of SS 18/8 immersed in Artificial Saliva+ENO (Bode plots).

It is observed from Table 2, that in the presence of ENO, the corrosion resistance of $\mathrm{SS} 18 / 8$ in AS decreases. This is revealed by the fact that in the presence of ENO, $R_{\mathrm{t}}$ value decreases (Figure 5), impedance value decreases and $C_{\mathrm{dl}}$ value increases.

\section{Implication}

Corrosion resistance of SS 18/8 alloy in artificial saliva decreases in the presence of ENO. Hence people clipped with orthodontic wire made of SS 18/8 alloy should avoid taking ENO orally. 


\section{Summary and Conclusions}

Outcome of the study

Corrosion resistance of SS 18/8 alloy in artificial saliva (AS), in the absence and presence of ENO has been investigated by polarization study and AC impedance spectra. It is inferred that the corrosion resistance of SS 18/8 alloy in artificial saliva decreases in the presence of ENO. This is revealed by a decrease in $L P R$ value, a decrease in $R_{\mathrm{t}}$ value, a decrease in impedance value, an increase in corrosion current, and an increase in double layer capacitance value. Hence it implies that people clipped with orthodontic wire made of SS 18/8 alloy should avoid taking ENO orally (Table 3, Figure 8).

Table 3. Comparison of corrosion parameters.

\begin{tabular}{ccc}
\hline Corrosion Parameters & Artificial Saliva (AS) & AS+ENO 500 ppm \\
\hline$L P R, \mathrm{Ohm} \cdot \mathrm{cm}^{2}$ & $3.488 \cdot 10^{6}$ & $1.629 \cdot 10^{6}$ \\
$R_{\mathrm{t}}, \mathrm{Ohm} \cdot \mathrm{cm}^{2}$ & 37796 & 3068 \\
Impedance, $\log (\mathrm{Z} / \mathrm{Ohm})$ & 4.857 & 3.954 \\
Corrosion current, $\mathrm{A} / \mathrm{cm}^{2}$ & $1.447 \cdot 10^{-8}$ & $2.637 \cdot 10^{-8}$ \\
Double layer capacitance, $\mathrm{F} / \mathrm{cm}^{2}$ & $1.349 \cdot 10^{-10}$ & $16.62 \cdot 10^{-10}$ \\
\hline
\end{tabular}

\section{$\square$ AS +ENO 500 ppm $\quad$ Artificial Saliva (AS)}

\begin{tabular}{|c|c|c|}
\hline double layer capacitance & $\begin{cases}16.62 & \times 10^{-10} \\
1.349 & \\
2.637 & \times 10^{-8} \\
1.447 & \end{cases}$ & $\begin{array}{l}\text { Corrosion resistance of } \\
\text { SS } 18 / 8 \text { alloy in artificial } \\
\text { saliva (AS), in presence } \\
\text { of ENO decreases }\end{array}$ \\
\hline $\begin{array}{r}\text { impedance } \\
\text { Rt }\end{array}$ & $\begin{array}{l}3.954 \\
4.857 \\
3068 \\
37796\end{array}$ & $\begin{array}{l}\text { Comparison of } \\
\text { corrosion parameters }\end{array}$ \\
\hline LPR & & $3.488 \cdot 10^{6}$ \\
\hline
\end{tabular}

Figure 8. Corrosion resistance of SS $18 / 8$ alloy in artificial saliva (AS) in the presence of ENO decreases. 


\section{References}

1. J. Kamiński, K. Małkiewicz, J. Rębiś and T. Wierzchoń, The effect of glow discharge nitriding on the corrosion resistance of stainless steel orthodontic arches in artificial saliva solution, Arch. Metall. Mater., 2020, 65, 375-384.

2. E. Erwansyah and C. Susilowati, The effect of snakefruit extract (Salacca zalacca) in inhibiting the release of chromium $(\mathrm{Cr})$ and nickel $(\mathrm{Ni})$ ion from stainless steel orthodontic wire to saliva, Int. J. Appl. Pharm., 2019, 11, no. 4, 33 -36.

3. I.Musa Trolic, N.L. Serdarevic, Z. Todoric, S. Spalj A. Budimir and H.O. Curkovic, Corrosion of orthodontic archwires in artificial saliva in the presence of Lactobacillus reuteri, Surf. Coat. Technol., 2019, 370, 44-52. doi: 10.1016/j.surfcoat.2019.04.081

4. N. Simionescu, A. Ravoiu and L. Benea, Electrochemical in vitro properties of 316L stainless steel for orthodontic applications, Rev. Chim., 2019,70, no. 4, 1144-1148. doi: 10.37358/RC.19.4.7081

5. V. Agnes Brigitta, C. Thangavelu and S. Rajendran, Effects of tablet on orthodontic wire made of SS 316L alloy in Artificial Saliva, Int. J. Res. Anal. Rev., 2019, 6, no. 1, 10001005.

6. A. Anandan, S. Rajendran, J. Sathiya Bama and D. Sathiya Raj, Influence of some tablets on corrosion resistance of orthodontic wires made of SS 316L alloy in artificial saliva, Int. J. Corros. Scale Inhib., 2017, 6, 132-141. doi: 10.17675/2305-6894-2017-6$\underline{2-3}$

7. Renita D'Souza, A. Chattree and S. Rajendran, Corrosion Resistance of SS 316L alloy in Artificial Saliva in the presence of Sparkle fresh Toothpaste, Port. Electrochim. Acta, 2017, 35, no. 6, 339-350. doi: 10.4152/pea.201706339

8. V.A. Brigitta, C. Thangavelu and S. Rajendran, Corrosion resistance of SS18/8, Gold18 carat, Gold 22 carat and SS 316L alloy in artificial saliva in the absence and presence of Vitavion Fort tablet 500 mg, Eur. J. Biomed. Pharm. Sci., 2018, 5, 864-871.

9. R. Saranya and S. Rajendran, Influence of D-glucose on corrosion resistance of SS 316L in the presence of artificial saliva, Rasayan J. Chem., 2018, 11, no. 1, 103-110. doi: 10.7324/RJC.2018.1111747

10. M. Zhang, Y. Yang, C. Song, Y. Bai and Z. Xiao, Effect of the heat treatment on corrosion and mechanical properties of CoCrMo alloys manufactured by selective laser melting, Rapid Prototyping J., 2018, 24, no. 7, 1235-1244.

11. C.E. Savencu, L.V. Costea, M.L. Dan, L. Porojan, Corrosion behaviour of Co-Cr dental alloys processed by alternative CAD/CAM technologies in artificial saliva solutions, Int. J. Electrochem. Sci., 2018, 13, no. 4, 3588-3600.

12. https://www.eno.co.in/products/eno-fruit-salt-sachet/

13. R. Nagalakshmi, L. Nagarajan, R.J. Rathish, S.S. Prabha, N. Vijaya, J. Jeyasundari and S. Rajendran, Corrosion resistance of SS 316L in artificial urine in the presence of DGlucose, Int. J. Nano. Corr. Sci. Engg., 2014, 1, 39. 
14. J.A. Thangakani, S. Rajendran, J. Sathiabama, R.M. Joany, R.J. Rathish and S.S. Prabha, Inhibition of corrosion of carbon steel in aqueous solution containing low chloride ion by Glycine-Zn ${ }^{2+}$ system, Int. J. Nano. Corr. Sci. Engg., 2014, 1, 50.

15. A. Nithya, P. Shanthy, N. Vijaya, R.J. Rathish, S.S. Prabha, R.M. Joany and S. Rajendran, Inhibition of corrosion of Aluminium by an aqueous extract of beetroot (Betanin), Int. J. Nano Corr. Sci. Engg., 2015, $2,1$.

16. A.C.C. Mary, S. Rajendran, H. Al-Hashem, R.J. Rathish, T. Umasankareswari and J. Jeyasundari, Corrosion resistance of mild steel in simulated produced water in the presence of sodium potassium tartrate, Int. J. Nano Corr. Sci. Engg., 2015, 1, 42.

17. A. Anandan, S. Rajendran, J. Sathiyabama and D. Sathiyaraj, Influence of some tablets on corrosion resistance of orthodontic wire made of SS 316L alloy in artificial saliva, Int. J. Corros. Scale Inhib., 2017, 6, no. 2, 132-141. doi: 10.17675/2305-6894-2017-6$\underline{2-3}$

18. C.O. Akalezi, C.E. Ogukwe, E.A. Ejele and E.E. Oguzie, Mild steel protection in acidic media using Mucuna pruriens seed extract, Int. J. Corros. Scale Inhib., 2016, 5, no. 2, 132-146. doi: 10.17675/2305-6894-2016-5-2-3

19. T.A. Onat, D. Yiğit, H. Nazır, M. Güllü and G. Dönmez, Biocorrosion inhibition effect of 2-aminopyrimidine derivatives on SRB, Int. J. Corros. Scale Inhib., 2016, 5, no. 3, 273-281. doi: $10.17675 / 2305-6894-2016-5-3-7$

20. A.S. Fouda, M.A. El-Morsy, A.A. El-Barbary and L.E. Lamloum, Study on corrosion inhibition efficiency of some quinazoline derivatives on stainless steel 304 in hydrochloric acid solutions, Int. J. Corros. Scale Inhib., 2016, 5, no. 2, 112-131. doi: 10.17675/2305-6894-2016-5-2-2

21. V.I. Vigdorovich, L.E. Tsygankova, E.D. Tanygina, A.Yu. Tanygin and N.V. Shel, Preservative materials based on vegetable oils for steel protection against atmospheric corrosion. I. Colza oil, Int. J. Corros. Scale Inhib., 2016, 5, no. 1, 59-65. doi: 10.17675/2305-6894-2016-5-1-5

22. P.N. Devi, J. Sathiyabama and S. Rajendran, Study of surface morphology and inhibition efficiency of mild steel in simulated concrete pore solution by lactic acid- $\mathrm{Zn}^{2+}$ system, Int. J. Corros. Scale Inhib., 2017, 6, no. 1, 18-31. doi: 10.17675/2305-6894-2017-6-1-2 